\title{
PENGEMBANGAN BAHAN AJAR MENULIS PUISI SEBAGAI UPAYA MEWUJUDKAN LITERASI SASTRA DI SEKOLAH DASAR
}

\author{
M. Habibi', Chandra ${ }^{2}$, Nana Fauzana Azima ${ }^{3}$ \\ Surel:bjhabibi147@gmail.com
}

\begin{abstract}
This research is a type of development research (Research and The Development) which aims to produce poetry writing teaching materials using various valid creative techniques used in learning to write poetry. Based on the development activities and the results of the teaching material validation, it was concluded that the poetry writing materials using various creative techniques were declared valid and suitable for use in poetry writing learning in grade IV elementary school. Overall, the requirements for developing teaching materials have been fulfilled in the development activities carried out. Based on the validator's assessment of the aspects of content, language, presentation, and graphic feasibility. Teaching materials as a whole are suitable for use in an effort to improve students' skills in writing poetry.
\end{abstract}

Keywords: Literacy, Teaching Materials

\begin{abstract}
ABSTRAK
Penelitian ini merupakan jenis penelitian pengembangan (Research and The Development) yang bertujuan menghasilkan bahan ajar menulis puisi menggunakan berbagai teknik kreatif yang valid digunakan dalam pembelajaran menulis puisi. Berdasarkan kegiatan pengembangan dan hasil validasi bahan ajar, disimpulkan bahwa bahan ajar menulis puisi menggunakan berbagai teknik kreatif dinyatakan valid dan cocok untuk digunakan dalam pembelajaran menulis puisi di kelas IV SD. Secara keseluruhan, persyaratan untuk mengembangkan bahan ajar telah terpenuhi dalam kegiatan pembangunan yang dilakukan. Berdasarkan penilaian validator tentang aspek kelayakan konten, bahasa, presentasi, dan grafik. Bahan ajar secara keseluruhan sesuai untuk digunakan dalam upaya meningkatkan keterampilan siswa dalam menulis puisi.
\end{abstract}

\section{Kata Kunci: Literasi, Bahan Ajar}

\section{PENDAHULUAN}

Literasi bukan hanya tentang kemampuan membaca dan menulis. Secara luas, literacy erat kaitannya dengan istilah kemahirwacanaan, yaitu kemampuan berbahasa keseluruhan mencakup kemampuan menyimak, berbicara, membaca, dan menulis, serta kemampuan berpikir yang menjadi elemen di dalamnya (Joyo, 2018). Literasi sastra merupakan dimensi literasi yang memfokuskan kajian terhadap sastra dan berbagai elemennya. Literasi sastra bertujuan agar nilai-nilai etika, estetika, dan moral dapat digali secara lebih luas dan diimplementasikan untuk kehidupan yang lebih baik (Sayekti, 2015).

Literasi sastra perlu dibudayakan sejak Sekolah Dasar (SD) agar kecintaan siswa terhadap sastra memiliki pondasi yang baik. 
Sastra memiliki peranan penting dalam pembentukan kepribadian siswa. Sastra mengajarkan dan mengenalkan siswa tentang hidup dan kehidupan. Pembelajaran sastra memiliki banyak manfaat bagi siswa, yaitu: (a) menumbuhkan kesenangan, kegembiraan dan keceriaan, (b) mengembangkan imajinasi siswa, membantu mereka berpikir tentang alam dan kehidupan, (c) memberikan pengalaman baru yang mampu dirasakan dan mengalaminya sendiri, (d) mengembangkan wawasan dan pengetahuan siswa tentang perilaku manusia, (e) mempresentasikan dan memperkenalkan anak-anak kepada hal-hal universal (Huck, 1978)

Pembelajaran sastra di SD terdiri atas (a) apresiasi sastra reseptif dan (b) apresiasi sastra produktif. Apresiasi sastra reseptif menekankan pada proses penikmatan yang dapat dilakukan melalui kegiatan membaca, mendengarkan atau menonton pertunjukan drama dan pembacaan puisi. Sedangkan apresiasi sastra ekspresif atau produktif dapat dilakukan dengan melatih siswa untuk menulis dan membaca puisi, menulis cerita atau sinopsis, dan bermain drama.

Puisi adalah karya sastra dengan bahasa yang dipadatkan, disingkat, dan diberi irama dengan bunyi yang menyatu dan pilihan katakata yang variatif atau imajinatif (Waluyo, 1987). Menulis puisi adalah keterampilan berbahasa yang diperlukan untuk meningkatkan kualitas pembelajaran. Menulis puisi perlu diperkenalkan sejak SD, karena menulis adalah salah satu alat /media yang dapat digunakan siswa untuk mengkomunikasikan pikiran dan perasaannya (Habibi \& Chandra, 2018). Pembelajaran menulis puisi seharusnya memungkinkan siswa untuk menyampaikan ide, gagasan, perasaan, dan pengalaman mereka secara puitis. Guru dapat membantu dan membimbing siswa untuk muncul dan mengembangkan ide, dan mengaturnya menjadi puisi sederhana.

Pembelajaran menulis puisi terasa sulit, disebabkan siswa tidak mampu mengimajinasikan objek atau hal-hal yang hendak disampaikan. Di samping itu, siswa juga kesulitan menempatkan ide dan pemikiran mereka ke dalam bait-bait puisi (Harper, 2007). Pola pembelajaran yang benar, penggunaan model, strategi, dan metode yang tepat akan membantu siswa dalam menuangkan imajinasi mereka ke dalam puisi. Selain itu, penggunaan bahan ajar yang tepat turut membantu dan membimbing siswa dalam melaksanakan proses penulisan puisi yang tepat.

Kesiapan bahan ajar termasuk faktor penentu berhasil tidaknya suatu pembelajaran. Bahan ajar adalah hal utama yang tidak dapat dipisahkan dari kegiatan belajar yang mampu mengantarkan siswa menguasai tujuan pembelajaran (Sudjana, 2011). Bahan ajar untuk menulis puisi harus mengandung tahap penulisan yang jelas dan sistematis, sehingga mampu mengarahkan siswa untuk menuangkan imajinasi mereka ke dalam beberapa bait puisi. Hal paling penting, bahan ajar menulis puisi harus menuntut keaktifan siswa, memberikan pengajaran dan pengalaman yang menarik. Sehingga muncul kepekaan sastra pada siswa sebagai upaya menumbuhkan kebiasaan mengapresiasi sastra, khususnya apresiasi puisi (Gilbert \& Graham, 2010).

Kenyataan di lapangan, bahan ajar yang digunakan guru dalam pembelajaran menulis puisi, terutama di kelas empat sekolah dasar tidak sesuai dengan tuntutan di atas. Bahan ajar yang digunakan hanya terbatas menugaskan siswa membuat puisi berdasarkan tema atau gambar yang ditampilkan. Bahan ajar tidak menyajikan proses penulisan yang dapat membantu siswa melakukan kegiatan menulis yang tepat. Selain itu, bahan ajar juga tidak menggunakan strategi/ teknik yang cocok untuk dikolaborasikan dalam proses penulisan puisi.

Mengatasi permasalahan di atas, maka perlu dirancang bahan ajar yang sesuai dengan karakteristik dan kebutuhan siswa dalam menulis puisi. Bahan ajar yang mampu mengarahkan dan membimbing siswa dalam melakukan kegiatan menulis puisi yang baik. Bahan ajar yang mengadopsi strategi/teknik yang tepat sehingga pembelajaran terasa menyenangkan dan dapat memudahkan siswa 
dalam membuat puisi. Ada beberapa teknik menarik yang dapat digunakan dalam mengembangkan bahan ajar untuk menulis puisi ini, yaitu teknik Peta Pasang Kata, teknik Ascrostic, teknik Media Gambar, dan teknik Melengkapi.

Teknik Peta Pasang Kata adalah teknik yang berfokus pada keberanian siswa untuk memasangkan kata-kata dengan bebas tetapi imajinatif. Siswa diberi kebebasan untuk memilih kata-kata yang kuat, kuat, khas dan solid sesuai temanya. Kata-kata ini dapat dikembangkan menjadi sebuah larik, kemudian menjadi sebuah kelopok larik (bait) yang akan membangun puisi (Sutedjo, 2008). Akrostik adalah teknik menulis puisi yang diawali dengan memikirkan sebuah nama. Nama yang dipilih akan menjadi acuan dalam mengembangkan larik-larik puisi. Setiap huruf dari nama yang dipilih akan menjadi huruf pertama pada setiap larik yang dikembangkan. Pengembangan larik berdasarkan huruf-huruf, disesuaikan dengan tema puisi (Sudibyo, 2008).

Selanjutnya, pembelajaran menulis puisi menggunakan gambar adalah teknik yang sangat direkomendasikan oleh para ahli. Gambar yang terlihat diam dan hening, banyak memberikan makna dan tafsiran kepada mereka yang memiliki rasa sensitif dan penuh imajinasi. Penggunaan gambar dalam menulis puisi menekankan keaktifan siswa untuk mengeksplorasi dan mengekspresikan imajinasi dan pemikiran mereka terhadap gambar yang dilihat (Tarigan, 2008). Menulis puisi dengan teknik melengkapi adalah praktik dasar menulis puisi. Mengisi konten puisi, hingga mengakhiri puisi dengan carayang menarik. Teknik ini juga melatih siswa agar siswa dapat beradaptasi dengan cepat dengan gaya puisi yang akan diselesaikan.

Pengembangan bahan ajar menulis puisi menggunakan berbagai teknik kreatif seperti yang dijabarkan di atas, diharapkan dapat menuntun siswa mengapresiasi sastra. Kemampuan siswa mengapresiasi sastra melalui kegiatan menulis puisi dan membacakannya, secara tidak langsung telah mengajarkan siswa agar memiliki sikap melek sastra.

\section{METODE PENELITIAN}

Penelitian ini merupakan jenis penelitian pengembangan (Research and The Development) yang bertujuan menghasilkan bahan ajar menulis puisi menggunakan berbagai teknik kreatif yang valid digunakan dalam pembelajaran menulis puisi. Model pengembangan yang digunakan dalam proses memproduksi bahan ajar adalah model ADDIE. ADDIE adalah akronim dari tahapan pengembangannya yang terdiri atas:: Analysis, Design, Development, Implementation, dan Evaluation (Molanda, 2015). Tahapan model pengembangan bahan menulis puisi mengikuti tahapan tersebut.

Pertama, tahap analysis. Bertujuan untuk menyelidiki berbagai permasalahan bahan ajar yang digunakan dalam pembelajaran. Kemudian dilanjutkan dengan merumuskan halhal atau kondisi yang dibutuhkan dalam mengembangkan bahan ajar untuk menulis puisi. Kegiatan formulasi ini adalah jawaban atas masalah yang ditemukan. Pada tahap analisis ada 3 kegiatan, yaitu: analisis kebutuhan, analisis kurikulum, dan analisis siswa. (a) Analisis kebutuhan bertujuan untuk mengungkapkan masalah dasar yang diperlukan dalam mengembangkan bahan ajar menulis puisi menggunakan berbagai teknik kreatif. Hal-hal yang dianalisis yang perlu dianalisis adalah rencana pembelajaran dan bahan ajar. (b) Analisis kurikulum dilakukan dengan melihat ruang lingkup KD dan konsep yang terkandung dalam $\mathrm{KD}$, dan tugas-tugas yang akan diberikan untuk mencapai standar KD. (c) Analisis siswa adalah studi tentang karakteristik siswa termasuk tingkat perkembangan bahasa, membaca dan menulis keterampilan, dan pengetahuan latar belakang lainnya. Identifikasi perilaku dan karakteristik siswa sangat diperlukan untuk menentukan kualitas individu yang dapat digunakan sebagai panduan dalam perencanaan pembelajaran (Uno, 2007) 
Kedua, tahap desain adalah kegiatan merancang bahan ajar untuk menulis puisi menggunakan berbagai teknik kreatif untuk siswa SD kelas lima. Bahan ajar yang dirancang memperhatikan hal-hal berikut (a) Kesesuaian materi yang dipilih dengan kurikulum (KI dan KD). (b) Pemilihan sumber pembelajaran pendukung (kesesuaian sumber terhadap tema dan teknik menulis). (c) Penentuan urutan proses belajar menulis puisi sesuai teknik pembelajaran yang digunakan.

Mempertimbangkan kesesuaian bahan ajar yang dikembangkan dengan alokasi waktu yang tersedia. (e) Prosedur untuk menulis bahasa yang akan digunakan (tingkat keterbacaan yang mudah dimengerti). (f) Bagaimana menyajikan materi sesuai dengan konsep pengembangan bahan ajar menulis puisi menggunakan berbagai teknik kreatif.

Ketiga, tahap pengembangan. Tujuan dari tahap pengembangan adalah untuk menghasilkan bahan ajar menulis puisi yang valid yang digunakan. Tahap ini mencakup validasi bahan ajar oleh para ahli yang bertujuan untuk mendapatkan masukan tentang keseluruhan isi materi yang terkandung dalam bahan ajar yang dikembangkan. Jika perangkat pembelajaran yang dikembangkan belum valid, maka revisi dibuat. Tetapi jika perangkat pembelajaran valid, uji coba terbatas dilakukan untuk melihat kepraktisan dan keefektifan perangkat dalam membantu siswa melakukan kegiatan penulisan puisi. Fase pengembangan meliputi tes validitas, kepraktikalitas dan efektivitas. Uji validitas dilakukan dengan memvalidasi bahan ajar oleh para ahli yang bertujuan untuk mendapatkan masukan tentang konten keseluruhan materi yang terkandung dalam bahan ajar untuk menulis puisi

.Ada 2 jenis validitas yang dipertimbangkan dalam pengembangan bahan ajar ini, yaitu: (1) Validitas konten, yaitu apakah bahan ajar menulis puisi yang dirancang sesuai dengan pemilihan KI dan KD dalam pembelajaran menulis puisi di kelas IV Sekolah Dasar . (2) Validitas konstruk, yaitu apakah komponen perangkat pembelajaran telah sesuai dengan elemen pengembangan yang ditetapkan.

Nilai validitas bahan ajar menulis puisi diperoleh dengan menggunakan lembar validasi bahan ajar. Validator akan memberikan penilaian pada skala 1-4 pada setiap aspek yang dinilai. Nilai masing-masing aspek kemudian dijumlahkan dan rata-rata dicari. Lebih lanjut dapat dilihat dalam rumus validitas yang dikemukakan oleh Widjajanti (2008) berikut:

$$
R=\frac{\sum_{i=1}^{n} V i j}{n m}
$$

\section{Keterangan}

$\mathrm{R}$ : Skor rata-rata hasil penilaian ahli.

Vij : Skorkumulatif dari hasil penilaian ahli j terhadap kriteria i

$\mathrm{n} \quad$ : Jumlah ahli/praktisi yang menilai

$\mathrm{m}$ : Jumlah kriteria

Nilai rata-rata yang diperoleh dikonfirmasikan ke dalam tingkatan kriteria berikut:

Tabel 1. Kriteria Tingkat Validitas

\begin{tabular}{cc}
\hline Category & Range \\
\hline $\mathbf{1 , 0 0}-\mathbf{1 , 9 9}$ & Invalid \\
\hline $\mathbf{2 , 0 0}-\mathbf{2 , 9 9}$ & Kurang Valid \\
\hline $\mathbf{3 , 0 0}-\mathbf{3 , 4 9}$ & Valid \\
\hline $\mathbf{3 , 5 0}-\mathbf{4 , 0 0}$ & Sangat Valid \\
\hline
\end{tabular}

\section{HASIL DAN PEMBAHASAN}

\section{Validitas Bahan Ajar}

Salah satu tujuan yang ingin dicapai dalam penelitian ini adalah menghasilkan bahan ajar menulis puisi menggunakan berbagai teknik kreatif untuk siswa SD kelas empat yang valid. Validitas adalah tingkat kesesuaian dari alat ukur yang dikembangkan dalam mengukur apa yang akan diukur. Keabsahan tindakan terbaik apa yang dimaksudkan untuk diukur. Ini berarti bahwa barang atau tugas terbaik secara hati-hati dipilih untuk mewakili tonggak perkembangan dan perilaku kunci (Otto, 2010). Validitas bahan ajar untuk menulis puisi menggunakan berbagai teknik kreatif dimaksudkan sebagai tingkat validitas atau kelayakan bahan ajar 
untuk meningkatkan keterampilan menulis puisi siswa kelas IV SD.

Validitas bahan ajar menulis puisi diperoleh dengan melakukan uji validasi bahan ajar. Kegiatan validasi dilakukan oleh para ahli yang memahami konsep pengembangan bahan ajar dalam ruang lingkup mata pelajaran B.Indonesia di SD. Jumlah validator (ahli) yang berperan dalam kegiatan validasi bahan ajar adalah 3 orang. Berikut ini diuraikan hasil penilaian bahan ajar untuk menulis puisi oleh ketiga validator.

Tabel 2. Hasil Validasi Bahan Ajar

\begin{tabular}{|c|c|c|c|}
\hline No & Aspek yang Dinilai & $\begin{array}{l}\text { Skor } \\
\text { Rata } \\
\text {-rata }\end{array}$ & $\begin{array}{c}\text { Kate } \\
\text { gori }\end{array}$ \\
\hline (1) & (2) & (3) & (4) \\
\hline \multicolumn{4}{|c|}{ A. Aspek Kelayakan Isi } \\
\hline 1 & $\begin{array}{l}\text { Materi bahan ajar } \\
\text { menulis puisi sesuai } \\
\text { dengan karakteristik } \\
\text { siswa. }\end{array}$ & 3.75 & $\begin{array}{l}\text { Sangat } \\
\text { Valid }\end{array}$ \\
\hline 2 & $\begin{array}{l}\text { Materi bahan ajar } \\
\text { menulis puisi sesuai } \\
\text { dengan minat siswa. }\end{array}$ & 3.25 & Valid \\
\hline 3 & $\begin{array}{l}\text { Materi bahan ajar } \\
\text { menulis puisi sesuai } \\
\text { dengan kebutuhan } \\
\text { siswa dalam menulis } \\
\text { puisi. }\end{array}$ & 3.50 & $\begin{array}{l}\text { Sangat } \\
\text { Valid }\end{array}$ \\
\hline 4 & $\begin{array}{l}\text { Bahan ajar menulis } \\
\text { puisi dapat membangun } \\
\text { komunikasi antara } \\
\text { siswa dan guru. }\end{array}$ & 3.50 & $\begin{array}{l}\text { Sangat } \\
\text { Valid }\end{array}$ \\
\hline 5 & $\begin{array}{l}\text { Bahan ajar menulis } \\
\text { puisi memiliki tahapan } \\
\text { pembelajaran yang } \\
\text { terstruktur. }\end{array}$ & 4.00 & $\begin{array}{l}\text { Sangat } \\
\text { Valid }\end{array}$ \\
\hline 6 & $\begin{array}{l}\text { Bahan ajar menulis } \\
\text { puisi mengarahkan } \\
\text { siswa pada kegiatan } \\
\text { mengapresiasi sastra. }\end{array}$ & 3.50 & $\begin{array}{l}\text { Sangat } \\
\text { Valid }\end{array}$ \\
\hline 7 & $\begin{array}{l}\text { Bahan ajar menulis } \\
\text { puisi menambah } \\
\text { wawasan siswa tentang }\end{array}$ & 3.75 & $\begin{array}{l}\text { Sangat } \\
\text { Valid }\end{array}$ \\
\hline
\end{tabular}

\begin{tabular}{|c|c|c|c|}
\hline & cara membuat puisi. & & \\
\hline 8 & $\begin{array}{l}\text { Bahan ajar menulis } \\
\text { puisi mengandung } \\
\text { nilai-nilai moral dan } \\
\text { sosial. }\end{array}$ & 3.50 & $\begin{array}{l}\text { Sangat } \\
\text { Valid }\end{array}$ \\
\hline & Total & 28.75 & Sangat \\
\hline & Rata-rata & 3.59 & Valid \\
\hline (1) & & (3) & (4) \\
\hline
\end{tabular}

\section{B. Aspek Kebahasaan}

\begin{tabular}{|c|c|c|c|}
\hline 9 & $\begin{array}{l}\text { Keterbacaan bahan ajar } \\
\text { dengan memperhatikan } \\
\text { sesuai tidaknya tema } \\
\text { puisi bagi siswa. }\end{array}$ & 3.50 & $\begin{array}{c}\text { Sangat } \\
\text { Valid }\end{array}$ \\
\hline 10 & $\begin{array}{l}\text { Kejelasan petunjuk dan } \\
\text { sistematika pengerjaan } \\
\text { tugas dalam bahan ajar } \\
\text { menulis puisi. }\end{array}$ & 3.50 & $\begin{array}{c}\text { Sangat } \\
\text { Valid }\end{array}$ \\
\hline
\end{tabular}

\begin{tabular}{|c|c|c|c|}
\hline 11 & $\begin{array}{l}\text { Kejelasan penyampaian } \\
\text { materi yang terdapat } \\
\text { dalam bahan ajar } \\
\text { menulis puisi. }\end{array}$ & 3.50 & $\begin{array}{l}\text { Sangat } \\
\text { Valid }\end{array}$ \\
\hline 12 & $\begin{array}{l}\text { Bahasa bahan ajar } \\
\text { menulis puisi sesuai } \\
\text { dengan kaidah bahasa } \\
\text { Indonesia yang baik } \\
\text { dan benar. }\end{array}$ & 3.50 & $\begin{array}{l}\text { Sangat } \\
\text { Valid }\end{array}$ \\
\hline 13 & $\begin{array}{l}\text { Bahan ajar menulis } \\
\text { puisi menggunakan } \\
\text { bahasa yang efektif dan } \\
\text { efisien (tepat). }\end{array}$ & 3.25 & Valid \\
\hline & Total & 17.25 & Valid \\
\hline & Rata-rata & $\mathbf{3 . 4 5}$ & vanu \\
\hline (1) & $(2)$ & (3) & (4) \\
\hline \multicolumn{4}{|c|}{ C. Aspek Penyajian } \\
\hline 14 & $\begin{array}{l}\text { Indikator pembelajaran } \\
\text { menulis puisi } \\
\text { dirumuskan dengan } \\
\text { jelas }\end{array}$ & 4.00 & $\begin{array}{c}\text { Sangat } \\
\text { Valid }\end{array}$ \\
\hline 15 & $\begin{array}{l}\text { Bahan ajar menulis } \\
\text { puisi mengurutkan } \\
\text { sajian yang sistematis. }\end{array}$ & 3.50 & $\begin{array}{l}\text { Sangat } \\
\text { Valid }\end{array}$ \\
\hline 16 & $\begin{array}{l}\text { Bahan ajar menulis } \\
\text { puisi memberikan } \\
\text { motivasi bagi siswa. }\end{array}$ & 3.25 & Valid \\
\hline 17 & $\begin{array}{l}\text { Tampilan bahan ajar } \\
\text { menulis puisi } \\
\text { memberikan daya tarik }\end{array}$ & 3.75 & $\begin{array}{l}\text { Sangat } \\
\text { Valid }\end{array}$ \\
\hline
\end{tabular}


ELEMENTARY SCHOOL JOURNAL VOLUME 9, NO. 1, JUNI 2019

\begin{tabular}{|c|c|c|c|}
\hline & bagi siswa. & & \\
\hline 18 & $\begin{array}{l}\text { Bahan ajar menulis } \\
\text { puisi menciptakan } \\
\text { interaksi dalam } \\
\text { pembelajaran. }\end{array}$ & 3.50 & $\begin{array}{c}\text { Sangat } \\
\text { Valid }\end{array}$ \\
\hline 19 & $\begin{array}{l}\text { Bahan ajar menulis } \\
\text { puisi disertai dengan } \\
\text { kelengkapan informasi. }\end{array}$ & 3.50 & $\begin{array}{c}\text { Sangat } \\
\text { Valid }\end{array}$ \\
\hline 20 & $\begin{array}{l}\text { Penggunaan ilustrasi } \\
\text { dan gambar sesuai } \\
\text { dengan tingkat } \\
\text { perkembangan siswa. }\end{array}$ & 3.75 & $\begin{array}{c}\text { Sangat } \\
\text { Valid }\end{array}$ \\
\hline & Total & 25.25 & Sangat \\
\hline & Rata-rata & 3.61 & Valid \\
\hline (1) & $(2)$ & (3) & (4) \\
\hline \multicolumn{4}{|c|}{ D. Aspek Kegrafikaan } \\
\hline 21 & $\begin{array}{l}\text { Bahan ajar menulis } \\
\text { puisi menggunakan } \\
\text { font arial narrow } \\
\text { dengan ukuran yang } \\
\text { jelas dibaca. }\end{array}$ & 4.00 & $\begin{array}{c}\text { Sangat } \\
\text { Valid }\end{array}$ \\
\hline 22 & $\begin{array}{l}\text { Lay out atau tata letak } \\
\text { bahan ajar menulis } \\
\text { puisi tertata dengan } \\
\text { baik. }\end{array}$ & 3.75 & $\begin{array}{c}\text { Sangat } \\
\text { Valid }\end{array}$ \\
\hline 23 & $\begin{array}{l}\text { Gambar yang terdapat } \\
\text { pada bahan ajar } \\
\text { membantu } \\
\text { memperjelasan isi } \\
\text { bahan ajar. }\end{array}$ & 3.50 & $\begin{array}{c}\text { Sangat } \\
\text { Valid }\end{array}$ \\
\hline 24 & $\begin{array}{l}\text { Desain tampilan bahan } \\
\text { ajar menarik dan tidak } \\
\text { monoton. }\end{array}$ & 3.75 & $\begin{array}{c}\text { Sangat } \\
\text { Valid }\end{array}$ \\
\hline 25 & $\begin{array}{l}\text { Penataan unsur tata } \\
\text { letak pada cover bahan } \\
\text { ajar memiliki kesatuan. }\end{array}$ & 3.50 & $\begin{array}{c}\text { Sangat } \\
\text { Vald }\end{array}$ \\
\hline 26 & $\begin{array}{l}\text { Penggunaan warna } \\
\text { menjadikan tampilan } \\
\text { bahan ajar lebih hidup. }\end{array}$ & 3.50 & $\begin{array}{c}\text { Sangat } \\
\text { Valid }\end{array}$ \\
\hline 27 & $\begin{array}{l}\text { Ukuran bahan ajar } \\
\text { sesuai standar ISO, A4 } \\
\text { fisik }(29 \mathrm{~cm} \text { x } 20,5 \mathrm{~cm})\end{array}$ & 3.75 & $\begin{array}{r}\text { Sangat } \\
\text { Valid }\end{array}$ \\
\hline & Total & 25.75 & Sangat \\
\hline & Rata-rata & 3.68 & Valid \\
\hline & Total Keseluruhan & 97 & Sangat \\
\hline & ata-rata Keseluruhan & 3.59 & Valid \\
\hline
\end{tabular}

Tabel di atas menunjukkan bahwa nilai rata-rata bahan ajar untuk aspek kelayakan konten adalah 3,59 dengan kategori sangat valid. Validitas bahan ajar dari aspek linguistik skor 3,45 dalam kategori valid. Selanjutnya, aspek materi ajar materi ajar bermotif skor 3,61 dengan kategori sangat valid. Sedangkan nilai bahan ajar untuk aspek grafis skor 3,68 dengan kategori sangat valid. Secara keseluruhan jika nilai setiap aspek diakumulasikan, maka nilai validitas bahan ajar untuk menulis puisi menggunakan berbagai teknik kreatif adalah 3,59 dengan kategori sangat valid. Skor menunjukkan bahwa bahan ajar yang dikembangkan valid untuk digunakan dalam pembelajaran menulis puisi. Bahan ajar yang dikembangkan sesuai dan tepat untuk digunakan dalam meningkatkan keterampilan menulis puisi siswa Sekolah Dasar.

\section{Pembahasan}

Validitas bahan ajar untuk menulis puisi menekankan pada validitas isi dan validitas konstruk. Validitas isi dilihat dari kesesuaian materi yang terkandung dalam bahan ajar, terutama dengan $\mathrm{KD}$ dalam menulis puisi. Sedangkan validitas konstruksinya dapat dilihat dari kesesuaian komponen bahan ajar dengan unsur-unsur bahan ajar yang ditetapkan pada tahap analisis (Riduwan, 2006)

Berdasarkan hasil validasi bahan ajar menulis puisi menggunakan berbagai teknik kreatif, diketahui bahwa keempat aspek penilaian bahan ajar dinyatakan valid. Berdasarkan aspek kelayakan isi, materi menulis puisi pada bahan ajar yang dikembangkan sesuai dengan standar bahan menulis puisi untuk siswa SD. Bahan ajar yang dikembangkan telah memenuhi aspek yang dibutuhkan oleh siswa dalam menulis puisi. Tahap-tahap penulisan yang dikolaborasikan dengan tahap penulisan puisi dan teknik yang digunakan, mampu membimbing siswa untuk menuangkan imajinasi mereka ke dalam puisi. Menulis puisi adalah kegiatan untuk mengekspresikan pikiran dan perasaan ke dalam bahasa yang imajinatif. Oleh karena itu, belajar menulis puisi harus membimbing siswa 
untuk membayangkan, memilih diksi yang tepat untuk mengekspresikan pikiran dan perasaan mereka (Anggraini, Shaifuddin, \& Sriyanto, 2013)

Bahan ajar yang dikembangkan juga memiliki tahapan yang terstruktur. Sehingga siswa benar-benar dibimbing dari tahap menghasilkan ide, memilih kata kunci, mengembangkan kata kunci ke dalam garis puisi, untuk menyusun garis puisi menjadi beberapa bait. Selain itu, penggunaan berbagai teknik penulisan memberikan pengetahuan baru bagi siswa bahwa menulis puisi dapat dilakukan dengan berbagai cara. Tema puisi yang diangkat dalam bahan ajar adalah tentang alam dan lingkungan. Secara tidak langsung memilih tema ini telah mengajarkan siswa tentang nilainilai moral dan sosial.

Berdasarkan aspek kebahasaan, bahasa bahan ajar dibuat sesuai dengan tingkat kemampuan siswa untuk memahami setiap uraian materi yang dijelaskan. Dalam mengembangkan bahan ajar, penggunaan bahasa merupakan faktor penting (Chandra, Mayarnimar, \& Habibi, 2018) Penggunaan bahasa yang meliputi pilihan berbagai bahasa, pemilihan kata, penggunaan kalimat yang efektif dan penyusunan paragraf, adalah hal-hal yang perlu dipertimbangkan dalam memastikan penggunaan bahan ajar. Meskipun isi bahan ajar sudah benar, tetapi menggunakan format yang konsisten, dan dikemas secara menarik, tetapi jika bahasa yang digunakan tidak efektif dan sulit dipahami bagi siswa, materi ajar tidak akan berarti (Belawati, 2003). Bahan ajar yang dikembangkan juga disertai dengan bahasa yang mengundang atau memotivasi. Tujuannya adalah agar siswa bersemangat menulis puisi dan menyelesaikan semua tahapan penulisan yang terkandung dalam bahan ajar.

Aspek penyajian berkaitan dengan metode yang digunakan dalam pengemasan bahan ajar sehingga mudah dipahami dan menarik bagi siswa. Dari segi aspek penyajian, materi bahan ajar disusun secara sistematis dan sesuai dengan indikator pembelajaran menulis puisi. Penyajian materi yang koheren dan sistematis dimaksudkan agar siswa terbiasa berpikir kritis(Belawati, 2003). Keterkaitan antara materi dijelaskan dengan hati-hati dan disertai dengan informasi lengkap yang membantu siswa mengerjakan setiap tugas yang diberikan. Agar bahan ajar terlihat menarik, bahan ajar disertai dengan beberapa ilustrasi dan gambar yang mendukung penyajian bahan ajar. Penggunaan ilustrasi dan gambar juga dimaksudkan agar siswa mudah memahami setiap materi yang dijelaskan.
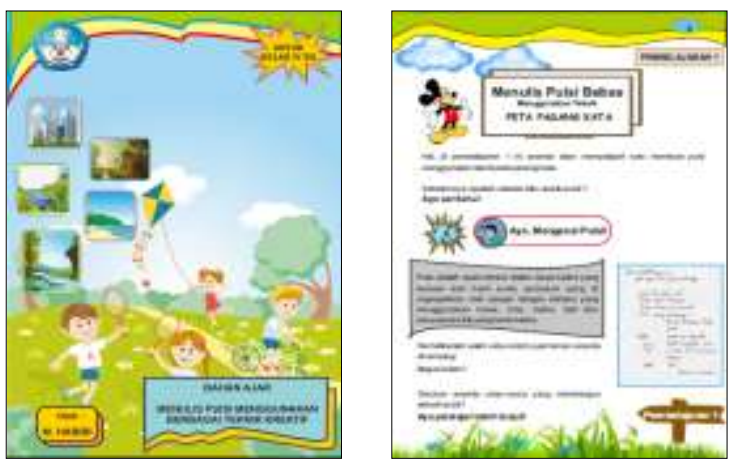

\section{Gambar 1. Tampilan Bahan Ajar}

Aspek grafis terkait dengan desain atau tampilan bahan ajar. Pola desain juga termasuk bagian penting dalam mengembangkan bahan ajar. Bagi siswa sekolah dasar, penampilan dan desain bahan ajar adalah hal pertama yang dianggap dan menjadi patokan utama dalam menentukan apakah bahan ajar itu menarik atau tidak. Aspek grafis dari bahan ajar termasuk ukuran buku, penggunaan huruf, tata letak, tata letak, ilustrasi sampul, penggunaan warna dan gambar. Ukuran buku termasuk tinggi $29 \mathrm{~cm}$ dan lebar 20,5 cm atau A4. Ukuran ini sesuai dengan standar ISO dan standar fisik untuk menulis buku (Gardjito, 2005). Bahan ajar yang dikembangkan telah memenuhi aspek ini. Bahan ajar menggunakan font sempit yang datang dengan ukuran yang dapat dibaca dengan jelas. Desain tampilan bahan ajar disajikan dalam berbagai bentuk sehingga tidak terkesan monoton. Penggunaan warna-warna cerah yang didominasi oleh hijau dan kuning, membuat bahan ajar terlihat lebih hidup. 


\section{SIMPULAN}

Berdasarkan kegiatan pengembangan dan hasil validasi bahan ajar, disimpulkan bahwa bahan ajar menulis puisi menggunakan berbagai teknik kreatif dinyatakan valid dan cocok untuk digunakan dalam pembelajaran menulis puisi di kelas IV SD. Secara keseluruhan, persyaratan untuk mengembangkan bahan ajar telah terpenuhi dalam kegiatan pembangunan yang dilakukan. Berdasarkan penilaian validator tentang aspek kelayakan konten, bahasa, presentasi, dan grafik. Bahan ajar secara keseluruhan sesuai untuk digunakan dalam upaya meningkatkan keterampilan siswa dalam menulis puisi.

\section{DAFTAR RUJUKAN}

Anggraini, D., Shaifuddin, M., \& Sriyanto, M. I. (2013). Peningkatan Kemampuan Menulis Puisi Dengan Menggunakan Metode Concept Sentence. Jurnal Mahasiswa PGSD. https://doi.org/10.1016/j.jbiosc. 2018.03.020

Belawati, T. (2003). Pengembangan Bahan Ajar. Jakarta: Universitas Terbuka.

Chandra, Mayarnimar, \& Habibi, M. (2018). Keterampilan Membaca dan Menulis Permulaan Menggunakan Model VARK untuk Siswa Sekolah Dasar. Jurnal Inovasi Pendidikan Dan Pembelajaran Sekolah Dasar, 2(1), 72-80. https://doi.org/https:// doi.org/10.24036/0201821100050-000011

Gardjito. (2005). Pedoman Standarisasi Fisik Buku Pelajaran. Jakarta: Pusat Perbukua,n Departemen Pendidikan Nasional.

Gilbert, J., \& Graham, S. (2010). Teaching Writing to Elementary Students in Grades 4-6: A National Survey Teaching Writing to Elementary Students in Grades 4-6: A National Survey. Source: The Elementary School Journal. https://doi.org/10.1086/ 651193

Habibi, M., \& Chandra. (2018). Strategi Direct
Writing Activity Sebagai Upaya Peningkatan Keterampilan Menulis Deskripsi Bagi Siswa Kelas II SD. Jurnal Inovasi Pendidikan Dan Pembelajaran Sekolah Dasar, 2(1), 1-11. https://doi. org/https://doi.org/10.24036/02018211000 32-0-00

Harper, G. (2007). 'Creative writing'? New Writing. https://doi.org/10.1080/ 14790720708668958

Huck, C. (1978). Children Literature in The Elementary School. New York: Hol Rinerhart.

Joyo, A. (2018). Gerakan Literasi dalam Pembelajaran Bahasa Indonesia Berbasis Kearifan Lokal Menuju Siswa Berkarakter. Jurnal Kajian Bahasa, Sastra Dan Pengajaran (KIBASP), 1(2), 159-170. https://doi.org/https://doi.org/10.31539/ki basp.v1i2.193

Molanda, M. (2015). In Search of The Ellusive ADDIE Model. Pervormance Improvement. International Journal of Educational Technologi, 42(5), 34-36. https://doi.org/ https://doi.org/10.1002/pfi.21461

Otto, B. (2010). Language Development in Early Childhood (USA). Pearson Education.

Riduwan. (2006). Belajar Mudah Penelitian Untuk Guru, Karyawan dan Peneliti Pemula. Bandung: Alfabeta.

Sayekti, O. M. (2015). "Sastra Anak untuk Membangun Budaya Literasi." Trihayu: Jurnal Pendidikan Ke-SD-An,.

Sudibyo. (2008). Pembelajaran Menulis Puisi dengan Teknik Akrostik. Retrieved from http://gerbangpendidikan.blogspot.com

Sudjana, N. \& A. R. (2011). Media Pengajaran (Metode dan Pembuatan). Bandung: Sinar Baru Algensindo.

Sutedjo, K. (2008). Menulis kreatif; Kiat Cepat Menulis Puisi dan Cerpen. Yogyakarta: Nadi Pustaka. 
M.Habibi, Dkk: Pengembangan Bahan Ajar Menulis.....

Tarigan, H. G. (2008). Menulis Sebagai Suatu Keterampilan Berbahasa. Bandung: Angkasa.

Uno, H. B. (2007). Model Pembelajaran Menciptakan Proses Belajar Mengajar yang Kreatif dan Efektif. Jakarta: Bumi Aksara.

Waluyo, H. J. (1987). Teori dan Apresiasi Puisi. Jakarta: Erlangga. 